\title{
The Exchange of Populations and the Transformation of Two Mediterranean Cities, Adana and Mersin
}

\author{
By Asli Emine Comu*
}

The Exchange of Populations' Convention was signed on 30 January 1923 during the Lausanne Peace Conference. The agreement actually set down a compulsory exchange of populations between Greece and Turkey, which involved the Turkish and Muslim inhabitants of Greece as well as the Greek islands and the Greek and Orthodox inhabitants of the various towns in Turkey. The separation of the Greek and Turkish communities eventually led to major political, economic and social changes in both countries. In the newly emerged Turkish Republic, with the expulsion of the Greek community, Turkish leaders grasped the opportunity to reshape the political and economic structure of the country for their own benefit and that of their coreligionists who formed an alliance and funded their efforts to this end. Two Mediterranean cities, Adana and Mersin, will be taken as case studies to reflect the transformation in the political, economic and social structure of the Ottoman Empire and the Republic of Turkey during the century following 1830. The aim of this paper is to present a comprehensive analysis of the Exchange of Populations and its impact on the socioeconomic reconstruction of the two Mediterranean cities.

\section{Introduction}

The Exchange of Populations Convention was signed on 30 January 1923 during the Lausanne Peace Conference. The agreement actually set down a compulsory population transfer between Greece and Turkey, which involved all the Muslim population living in Greece as well as Greek islands except for Muslims living in the Western Thrace and all the Greek Orthodox population of all the Anatolian towns under Turkish control except for the ones living in Istanbul and its sub districts. In accordance with this agreement, approximately 1,6 million of people from both binding countries were forced to leave their hometowns behind and build up a new life in unfamiliar surroundings.

The Convention permanently severed the ties between migrants and the land of their origins. The migrants were not allowed to return to live in their former hometowns without the authorization of both contracting parties (Article I). By the seventh article of the same Convention, it was provided that the migrants were to lose the nationality of the country, which they were leaving and were to acquire the nationality of the country of their destination upon arrival. By breaking their ties with the countries of origin, the Convention worked for the integration of the migrant communities into their countries of resettlement. They were identified as nationals not foreigners. It also underlined the fact that their settlement in the countries of destination was permanent, not temporary. The Convention also imposed some binding obligations upon its

*Assistant Professor, Cukurova University, Turkey. 
signatories on the subject of immovable and movable property of the migrants. According to the eighth article of the Convention, migrants were free to take away with them or to arrange the transport of their movable property of any kind. All immovable property belonging to the migrants were to be liquidated independently of any measures of any kind (Articles IX).

The exchange was to start officially on 1 May 1923 but this date was later altered by agreement to May 1924. However, the majority of the exchangeable people had already left before the official date. Over one million Greeks had already left Turkey and the estimated 800,000 Muslims in Greece had been reduced by half due to prior forced displacements. ${ }^{1}$ Therefore, the Convention operated both to determine the status of the migrants who had left and to draw up the conditions for the exchange of the remaining population. It actually provided the legal basis for the expulsion of these unwanted minorities and put an end to the heterogeneous social structure of former Ottoman provinces.

This paper asserts that the Exchange of Populations played an important part in the transition from the Ottoman Empire to the Turkish Republic. In the first place, it helped to forge the long yearned for national unity or at least homogeneity in religious affiliation in the country. In the second place, with the expulsion of the Greek community, Turkish nationalist leaders grasped the opportunity to reshape the political and economic structure of the country for their own benefit. Two Mediterranean cities, Adana and Mersin, will be taken as case studies to reflect the economic and social transformation of Anatolia starting from the second half of the nineteenth century until the establishment of the Turkish Republic.

\section{The Background}

Adana and Mersin were part of the historical Ottoman Province of Adana, which situated on the southeastern part of the Anatolian Peninsula. This region, which is also known as Cilicia, was bordered by the Mediterranean in the south and the Taurus Mountains in the north. This province had/have large-sized fertile plains, which was/is the basis of its economic value. Thanks to its natural resources, it was a place of settlement since ancient times. The Ottoman control in the region went back to the sixteenth century and Adana and Mersin have stayed under Turkish control until this day.

The economy depended on agriculture and agriculture depended on the cultivation of several products, mainly wheat, cotton and sesame, whose cultivation was introduced in the region centuries ago. Among the diverse crops, cotton took the leading role and was mostly referred to as the most important and valuable product of the region. However, until the beginning of the nineteenth century, cotton production had no competitive nature and cotton was mostly consumed within the domestic market. International demand for Cilician cotton occurred during the second half of the nineteenth

1. M. Barutciski, "Lausanne Revisited: Population Exchanges in International Law and Policy," in Crossing the Aegean: An Appraisal of the 1923 Compulsory Population Exchange between Greece and Turkey, ed. Renee Hirschon (New York: Berghahn Books, 2003), 28. 
century due to the American Civil War, which deeply threatened the world cotton supply. In order to provide cotton for European textile manufacturers, especially British ones, expansion of the area under cotton cultivation was attempted and new alternatives to American cotton were sought by European powers led by Britain. ${ }^{2}$ Ottoman Empire also supported cotton production by granting various privileges and preferences. ${ }^{3}$ The suitability of the region for cotton production combined with international demand for cotton resulted in the extension of land under cultivation. Most of the land was concentrated in a few large landowners' hands. ${ }^{4}$ The average farm size in Adana was 45 donumsa donum is one-tenth of a hectare- and 46 percent of farms were over 50 donums. ${ }^{5}$ Irrigation projects, agricultural credits and usage of fertilizers and insecticides were applied to increase the yields of most crops under cultivation and to promote grain and cotton production. ${ }^{6}$

As a result, Adana which had been one of the main commercial centers of the Cilician Plains since the Phoenician times ${ }^{7}$ returned to its ancient glory in the second half of the nineteenth century. Adana became one of the main suppliers of raw materials and exported significant amount of its agricultural output to various regions including France, Cyprus, Italy, Syria and Austria via the port of Mersin. Cotton, sesame, various grains, mainly wheat and barley ${ }^{8}$ were exported alongside timber and animal products such as wool and leather. ${ }^{9}$ In return, Adana imported manufactured goods such as English, French and Indian clothing, Russian petroleum and other consumable goods including sugar, coffee and rice. ${ }^{10}$

Toward the end of the nineteenth century, as a result of this economic boom, Mersin emerged as a flourishing port town which had trade links with European and other major Mediterranean ports such as Alexandria, Jaffa, Haifa, Tripoli, Smyrna, Napoli, Antwerp and Geneva. In the early modern period, Silifke (Seleucia), Tarsus and Ayas (Laiazzo) were the main ports of the region where the commercial transactions were carried out. Trade gradually shifted from Tarsus to Mersin in the 1850s due to unbearable weather conditions in the former on the account of the huge marsh that lay to the

2. D. Quataert, Ottoman Reform and Agriculture in Anatolia 1876-1908 (Ph.D.,diss, UCLA, 1973), 157.

3. B. Varlık, Emperyalizmin Çukurova'ya Girişi [Introduction to Çukurova imperialis] (Ankara: Tüm İktisatçılar Birliği, 1977), 42.

4. M. Toksöz, The Çukurova: From Nomadic Life to Commercial Agriculture, 1800-1908 (Ph.D., diss, SUNY Binghamton University, 2000), 248-249.

5. E.G. Mears, Modern Turkey: A Politico-Economic Interpretation 1908-1923 Inclusive (New York: The Macmillan Company, 1924), 296.

6. M. Toksöz, 249.

7. V. Langlois, Voyage dans la Cilicie et dans les Montagnes du Taurus [Travel to Cilicia and the Taurus Mountains] (Paris: Benjamin Duprot, 1861), 30.

8. W. B. Barker, Lares and Penates, or, Cilicia and Its Governors (London: Ingram, Cooke and Co., 1853), 118.

9. V. Cuinet, La Turquie D’Asie [Asian Turkey], vol.6 (İstanbul: İsis, 2001), 150.

10. Ibid. 
southwest of Tarsus. ${ }^{11}$ As trade kept growing during this period, the barely inhabited town received new settlers from the North Aegean Islands, mainly from Samos and Chios, Cappadocia, and Cyprus. By 1860, 600 Greek families were thought to inhabit the town. ${ }^{12}$ In addition to Greek migrants, Maronite families came from Lebanon, as did numerous members of the Orthodox community in Syria. The main motives were economic and as a result, the population of Mersin rose rapidly, reaching almost 22,000 in $1893 .{ }^{13}$ The construction of Adana-Mersin Railway in 1883, without doubt, facilitated the exchange of goods and the expansion of areas under cultivation throughout the region.

The region did not only experience a significant increase in the volume of trade but also manufacturing industry began to flourish in the late nineteenth century. The first mechanized cotton gins were generally established by British and French manufacturers in Adana. These British and French businessmen were followed by Greek immigrants who subsequently established additional mechanized cotton ginneries in the region. For instance, in 1885, a Greek immigrant called Tripani built a cotton gin in 1898 and later he began yarn manufacture. Cosmo Simyonoğlu and Mavromati, two other Greek immigrants, also founded cotton gins in Adana and Tarsus respectively. In 1914, the spinning and weaving mills in Tarsus and Adana contained a total of 42,000 spindles that used 10,000 bales of local cotton. In good years, these mills together consumed 40 percent of the local cotton crop and daily produced some 72,000 kilograms of yarn. ${ }^{14}$ In addition, Greeks owned 45,000 donums (4500 hectates) of land in Adana and 13,000 donums (1300 hectares) in Mersin. ${ }^{15}$ Although Greeks could be accepted as a minor community, their influence was not as insignificant as their number in the region. Actually, they made up the majority of upper class of Adana and Mersin.

Two groups of Greeks existed in the region, natives and migrants. The number of natives was approximately 2000. This Turkish-speaking group was composed of peasants and small shop-owners who did not have significant impact on the economic life of the region. The members of the other group migrated to the region from Kayseri ${ }^{16}$, Niğde, Konya, Cyprus, Mitylene and mainland Greece and comprised one of the highest-ranking classes in society. ${ }^{17}$ Kayseri, Konya or the Aegean islands were not randomly selected points of immigration. In fact, the Province of Adana had firm commercial relations with these mentioned districts for decades. The commercial traffic between Adana

11. R. Toledano, "Where have all the Egyptian Fallahin gone to? Labour in Mersin and Cukurova," in Kollokyum 19. yy'da Mersin ve Akdeniz Dünyası (Mersin: Mersin Üniversitesi Yayınları, 2002), 22.

12. E. Balta, "The Greek Orthodox Community of Mersina," in Kollokyum 19. yy'da Mersin ve Akdeniz Dünyası (Mersin: Mersin Üniversitesi Yayınları, 2002), 39.

13. Ş. Develi, Dünden Bugüne Mersin 1836-1990 [Mersin from past to today 1836-1990] (Mersin: MTSO Yayınları, 2001), 57.

14. D. Quataert, Ottoman Manufacturing in the Age of the Industrial Revolution (Cambridge: Cambridge University Press, 1993), 44.

15. Başbakanlık Osmanlı Arşivi (BOA), DH.EUM.5Sb, D:2, G: 24.

16. Kayseri is a middle-sized town located 300 kilometers in the North of Adana. Niğde and Konya are also located in Central Anatolia.

17. The Centre for Asia Minor Studies, Adana File, Population Section. 
and Kayseri was so intense that the merchants visited Adana 30-40 times a year. ${ }^{18}$ It is possible that some of these merchants decided to settle in Adana to control their business from there. Cosmo Simyonoğlu, who was mentioned above, was among those migrants from Kayseri.

Therefore, it could be stated that migration played a significant role in the economic development of the region in the late nineteenth century. Various groups of people were induced by the promises of quick profits in the province. In fact, most of them turned out to be successful businessmen. As thriving commercial centers in the Mediterranean, these cities delivered what they promised. Further migrations populated Adana and Mersin with people of different ethnicities and brought dynamism and cultural richness. However, this multi-religious and multi-ethnic composition of the population was reshaped by another major migration flow, set by the Lausanne Peace Conference in 1923. The Exchange of Populations brought homogeneity in a hitherto heterogeneous society.

\section{After the Implementation of the Exchange of Populations}

The Exchange of Populations brought a massive responsibility to both Turkey and Greece. In Turkey, the tough task of providing shelter to thousands of migrants was entrusted to the Ministry of Exchange, Reconstruction and Settlement. The primary job of the Ministry was to assign the regions for the settlement of migrants. According to the settlement scheme of the Ministry, Muslim migrants from Greece were simply divided into three groups, which were respectively farmer-vine dresser, tobacco cultivator and olive cultivator. ${ }^{19}$ The Ministry calculated that 395,000 migrants would be coming from Greece and selected ten areas for their settlement, which included Adana and Mersin. ${ }^{20}$

According to the local official sources, a total of 4937 migrants were settled in the city of Adana and its environs. ${ }^{21}$ In the case of Mersin, one source gave the number of migrants as $12,055 .^{22}$ Another source stated 3091 migrants were settled in the city. ${ }^{23}$ The official sources are quite inadequate to calculate the accurate number; but it is quite likely that their number was much closer

18. W. B. Barker, 118, 374.

19. K.1 Arı, Büyük Mübadele Türkiye'ye Zorunlu Göç 1923-1925 [The great exchange, forced migration to Turkey 1923-1925] (İstanbul: Tarih Vakfi Yurt Yayınları, 2003), 53.

20. Ibid.

21. The archival sources on the settlement of migrants in Adana and Mersin are divided between two institutions: The Provincial Directorate of Public Works and Settlement and the Provincial Special Administrative Unit. There are ddisorganized lists for migrants settled in Adana and its sub districts. However, no such list is available for the ones settled in Mersin. Petitions submitted by migrants in both cities actually provide additional information about the settlement process.

22. F. Emgili, "Türk-Yunan Nüfus Mübadelesinin Mersin'in Sosyo-Ekonomik Yapısına Etkileri," in Tarih İçinde Mersin Kollokyum II (Mersin: Mersin Üniversitesi Yayınları, 2005), 136.

23. C. Geray, Türkiye'den ve Türkiye'ye Göçler ve Göçmenlerin İskanı [Immigration and immigrants from Turkey and Turkey Settlement] (Ankara: Siyasal Bilgiler Fakültesi, 1962), Appendix 5. 
to the second number. Mersin was the main port of entry for migrants to the whole settlement region. However, not all of these migrants were settled in the town center; many of them were sent to the interior towns. In addition, the town did not have the capacity to absorb such a large influx of migrants. The number of people who left the town before and during the Exchange of Populations did not exceed $4000 .{ }^{24}$ Therefore, the estimated number could have been between 3000 and 5000 .

Adana and Mersin mainly received migrants from Serez (Serres), Demirhisar (Sidirokastro), Selanik (Thessaloniki), Alasonya (Elassona) and Crete, Heraklion. The majority of the migrants were farm laborers and a small percentage of them were workers, merchants, civil servants, coffee shop owners and shoemakers. ${ }^{25}$ In both cities, migrants were either settled in the city centers or in rural areas. There were two types of villages available for settlement; the newly built villages on the land of the abandoned Armenian and Greek farms and long-established migrant villages built as a result of former migration flows. In Adana, migrants who were settled in the center were given a residence and a piece of land or vineyard located in the outskirts of the city or a workshop in the town center. Most of the residences were left by the former Armenian and Greek residents of the city.

The same settlement program was also applied in Mersin. Migrants were given houses in the center and some of them were distributed pieces of land in varying sizes between 15 and 40 donums (1.5 and 4 hectares), while others were given small gardens less than 15 donums ( 1.5 hectares). Some parcels of land were situated in villages in the close vicinity of the city. Urban migrants were also provided with livelihood support to start a new living. Most of them were given shops or other businesses by the authorities. The owners of the abandoned property were Greek and Armenian inhabitants of the town who had fled or were deported in exchange for Muslims in Greece. New migrant settlements were also constructed on the land of abandoned Greek and Armenian farms in Mersin. The abandoned farms sited on huge tracts of fertile land suitable for commercial agriculture. These farms turned into migrant villages where about 30-50 families were provided with housing and land for agricultural activities. The Yuvanaki Farm can be given as an example for this type of settlement. This farm opened up for the settlements of migrants from Demirhisar (Sidirokastro) in 1924. Thirty-four huğs (four-roomed huts made of mud and straw) were constructed by the Ministry. ${ }^{26}$ The name of the farm was eventually changed to Demirhisar, town of origin of the migrants, after their settlement.

However, the settlement process did not proceed smoothly as mentioned above. Migrants faced with serious problems during and after their arrival. The majority of the migrant families complained about receiving insufficient amount of property, whose value was not equal to the value of the properties they left in Greece. Another major problem was the settlement of migrant

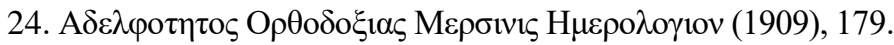
Branch.

25. The Archive of the Provincial Directorate of Public Works and Settlement, Mersin 26. Türkiye Cumhuriyet Arşivi (TCA), 272.80/3.8.2. 
groups in regions whose conditions of production were incompatible with their skills and knowledge. In addition, most of the migrants became the victims of disorder and lawlessness. Since most of the migrant families were not given the title deeds to prove the ownership of the distributed estates, some people established a claim on these properties. In 1934, in one of his speeches in the Turkish Grand National Assembly, Şükrü Kaya, the Minister of Interior, stated: "Abandoned land was distributed by the state to migrants who gradually improved and cultivated barren tracts of land. After a while, some people showed up with title deeds and drove out the migrants who were working on these fields." ${ }^{27}$ The Minister did not clarify who actually seized the migrant lands but some authors claimed that it was the local notables who captured these properties by fraudulent proceedings. ${ }^{28}$

Despite these stressing incidents, not much was done to ameliorate the living conditions of these migrant groups. Since the overwhelming proportion of migrants was agricultural laborers, small farmers and petty traders, they were bound to share the fate of their fellow members of these underprivileged classes. Their main contribution as stated by Şükrü Kaya was to strengthen the cohesion and homogeneity of the Turkish nation. ${ }^{29}$

It could be clearly seen that migrants from Greece were not able to replace those who were left before and after the implementation of the Exchange of Populations Convention. In general, migrants did not make much progress in the spheres of industry and trade under the presented circumstances. Migrants with agricultural background actively occupied with their land and made contributions to agricultural production. The urban migrants, on the other hand, became owners of small businesses and workshops in the cities and became involved in the crafts and retail business. The majority of them were members of middle class or lower middle class. But, of course, there were exceptions within the migrant community who had earned large amounts of money from industrial investments based on agriculture after their arrival to Turkey. It should be noted that the majority of these people either brought enough capital with them to start a business in the country or initially engaged in small businesses for a definite period to accumulate sufficient capital for investment in industry. For instance, a few wealthy migrant families from Heraklion, Crete, were given factories in Mersin and Tarsus in exchange for properties they left on the island. The Karamehmedaki family received an ice factory and a cotton ginnery in Mersin after their arrival. ${ }^{30}$ In a similar way, the Tütüner family from Crete was also given a cotton ginnery in Mersin where they mainly hired their

27. Quoted in S. Aksoy, 100 Soruda Türkiye'de Toprak Meselesi [The land issue in Turkey] (İstanbul: Gerçek Yayınevi, 1969), 56-57.

28. S. Yerasimos, Azgelişmişlik Sürecinde Türkiye [Underdevelopment Process in Turkey], vol.3 (İstanbul: Gözlem Yayınları, 1976), 1255.

29. Quoted in E. Ülker, "Assimilation of the Muslim Communities in the First Decade of the Turkish Republic (1923-1934)," European Journal of Turkish Studies [Online], Complete List 2007, paragraph 16.

30. The Archive of Public Works and Settlement Directorate, Mersin Branch, Karamehmedaki File. 
fellow countrymen as workers and thus supported indigent members of their community. $^{31}$

Although a limited number of migrants became wealthy and improved their status in society, they were not the richest and most financially supported group in the region. In accordance with government policies, local notables who cooperated with the Nationalist forces during the Greco-Turkish War became the richest and most powerful residents of the whole province. In other words, they stepped in to fill the economic gap left by the departure of Greek and Armenian residents.

The Karamehmet and Eliyeşil families were the prominent landlords in Tarsus who gave support to the Nationalist Movement during the war in Anatolia 1919-1922. The head of the Karamehmet family, Karamehmetzade Hafiz Mehmet Bey, along with his friend Müftüzade Sadık Pasha (Sadık Eliyeşil) founded the Society of Defense of Rights (Müdafaa-i Hukuk Cemiyeti) after the French occupation of Cilicia including Tarsus. They were known as the leaders of the Nationalist resistance in the town. After the war, the two families founded a business partnership and were entrusted with the operation of cotton and yarn factory that was abandoned by the Mavromati family in Tarsus. ${ }^{32}$ In later decades, the Karamehmet and Eliyeşil families bought another factory that once belonged to the Bodasaki family, another wealthy Greek family of the region. ${ }^{33}$

Another prominent businessman from Kayseri, Nuh Naci Yazgan, who was a delegate to the Sivas Congress and an important supplier of the Nationalist forces during the war, was awarded with the factory that was abandoned by the Greek Simyanoglu family in Adana. Nuh Naci Yazgan was twice elected as MP for Adana and served for two years until his resignation in 1924. He was among those businessmen and landlords who were from Kayseri and migrated to Cilicia, especially Adana after the departure of Greeks and Armenians. As stated above, Adana and Kayseri were historical trade partners. These businessmen from Kayseri also had strong commercial ties with the Adana region in the pre-Republican period and after the departure of Greeks and Armenians, they took over their businesses and replaced them in industry and trade. ${ }^{34}$ The lack of qualified manpower could be identified as their biggest opportunity, which smoothed the way for wealth accumulation. In this favorable business climate with supportive government policies, diligent and competent entrepreneurs, in other words, those who were determined and able to take the place of Greeks and Armenians took advantage of these opportunities and started to build their fortunes.

In addition to local notables, Nationalist MPs and their local allies in the government sector were induced by the new Turkish administration to participate in and contribute to commercial and industrial activities in Cilicia.

31. F. Emgili, Türk-Yunan Nüfus Mübadelesinin Mersin'in Sosyo-Ekonomik Yapısina Etkileri [Effects of Turkish-Greek Population Exchange on Socio-Economic Structure of Mersin], https://bit.ly/2Q2JZbG.

32. Vatan, 18 June 2008.

33. Şinasi Develi, 187.

34. A. E. Çomu, The Exchange of Populations and Adana 1830-1927 (İstanbul: Libra Kitap, 2011), 109. 
Yusuf Ziya Eraydın, a local agriculturist who sided with the Nationalists and served as a MP in the Turkish parliament during the Greco-Turkish $\mathrm{War}^{35}$, and Hacı Ömer Kutay, local Nationalist governor of one of Mersin's sub districts, were given the right to operate an abandoned cotton factory in Mersin. This factory was founded by a wealthy Armenian inhabitant of the city, Zelvian, in 1911. Eraydın and Kutay rant he factory until 1944 when it was sold to another Turkish businessman. ${ }^{36}$

\section{Conclusion}

To sum up, after the establishment of the Turkish Republic in 1923, the government under the control of the Nationalist forces took control of economic affairs and allocated resources to groups close to them. The economic power of the non-Muslim communities, which provided them priority over the Muslim population, was totally curtailed and a Turkish bourgeois class was developed to replace their position. In fact, the Exchange of Populations helped the Turkish authorities to develop strategies to implement their plans. The Turkish government's inattention to the settlement of migrants from Greece proved that the primary purpose of the forced population transfer was not that of accepting additional Muslim population but rather one of releasing the country from the economic domination of the nonMuslim population. It should be added that these migrant groups were considered quite helpful to the process of homogenization of the population. Since the migrant groups were absent during the struggle for Turkish national rights, they were not included in the strategic alliances that had already been formed during the war. Except for a small minority, large numbers of migrants underwent a rough transition; most of them could not adapt to their new environment and found themselves in serious financial straits. In following decades, they completely integrated into the rest of the society and led a modest life. On the other hand, owing to active government support, most of the allies of the Nationalist forces grew wealthy and powerful; they are still among the richest families in Turkey today.

35. Türk Parlamento Tarihi Milli Mücadele ve TBMM I. Dönem, vol.3, I. Dönem Milletvekillerinin Özgeçmişleri, ed. by Fahri Çoker (Ankara: Türkiye Büyük Millet Meclisi Yayınları, 1994), 788-89.

36. Ş. Develi, 185,188. 


\section{Bibliography}

\section{Primary Sources}

Başbakanlık Osmanlı Arşivi [Turkish Prime Ministry Archive]

The Archive of the Provincial Directorate of Public Works and Settlement

The Centre for Asia Minor Studies

Türkiye Cumhuriyet Arşivi (Turkish Republican Archive)

\section{Secondary Sources}

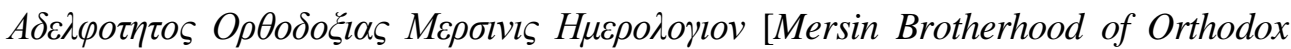
Calendar]. 1909.

Aksoy, S. 100 Soruda Türkiye'de Toprak Meselesi [The land issue in Turkey]. İstanbul: Gerçek Yayınevi, 1969.

Arı, K. Büyük Mübadele Türkiye'ye Zorunlu Göç 1923-1925 [The great exchange, forced migration to Turkey 1923-1925]. İstanbul: Tarih Vakfi Yurt Yayınları, 2003.

Balta, E."The Greek Orthodox Community of Mersina." In Kollokyum 19. yy'da Mersin ve Akdeniz Dünyası. Mersin: Mersin Üniversitesi Yayınları, 2002.

Barker, W. B. Lares and Penates, or, Cilicia and Its Governors. London: Ingram, Cooke and Co., 1853.

Barutciski, M. "Lausanne Revisited: Population Exchanges in International Law and Policy." In Crossing the Aegean: An Appraisal of the 1923 Compulsory Population Exchange between Greece and Turkey, edited by Renee Hirschon. New York: Berghahn Books, 2003.

Cuinet, V. La Turquie D’Asie [Asian Turkey]. vol.6. İstanbul: İsis, 2001.

Çomu, A. E. The Exchange of Populations and Adana 1830-1927. İstanbul: Libra Kitap, 2011.

Develi,Ş. Dünden Bugüne Mersin 1836-1990 [Mersin from past to today 1836-1990]. Mersin: MTSO Yayınları, 2001.

Emgili, F."Türk-Yunan Nüfus Mübadelesinin Mersin' in Sosyo-Ekonomik Yapısına Etkileri." In Tarih İçinde Mersin Kollokyum II. Mersin: Mersin Üniversitesi Yayınları, 2005.

Emgili, F. Türk-Yunan Nüfus Mübadelesinin Mersin'in Sosyo-Ekonomik Yapısına Etkileri [Effects of Turkish-Greek Population Exchange on Socio-Economic Structure of Mersin]. https://bit.ly/2Q2JZbG.

Geray, C. Türkiye'den ve Türkiye'ye Göçler ve Göçmenlerin İskanı [Immigration and immigrants from Turkey and Turkey Settlement]. Ankara: Siyasal Bilgiler Fakültesi, 1962.

Langlois, V. Voyage dans la Cilicie et dans les Montagnes du Taurus [Travel to Cilicia and the Taurus Mountains]. Paris: Benjamin Duprot, 1861.

Mears, E. G. Modern Turkey: A Politico-Economic Interpretation 1908-1923 Inclusive. New York: The Macmillan Company, 1924.

Quataert, D. Ottoman Manufacturing in the Age of the Industrial Revolution. Cambridge: Cambridge University Press, 1993.

Quataert, D. "Ottoman Reform and Agriculture in Anatolia 1876-1908." Ph.D., diss, UCLA, 1973.

Toksöz, M."The Çukurova: From Nomadic Life to Commercial Agriculture, 18001908." Ph.D., diss, SUNY Binghamton University, 2000. 
Toledano, R. "Where have all the Egyptian Fallahin gone to? Labour in Mersin and Cukurova." In Kollokyum 19. yy'da Mersin ve Akdeniz Dünyası. Mersin: Mersin Üniversitesi Yayınlar1, 2002.

Türk Parlamento Tarihi Milli Mücadele ve TBMM I. Dönem. vol.3. I. Dönem Milletvekillerinin Özgeçmişleri, edited by Fahri Çoker. Ankara: Türkiye Büyük Millet Meclisi Yayınları, 1994.

Ülker, E."Assimilation of the Muslim Communities in the First Decade of the Turkish Republic (1923-1934)." European Journal of Turkish Studies [Online].

Varlık, B. Emperyalizmin Çukurova'ya Girişi [Entry to imperialism Cukurova]. Ankara: Tüm İktisatçılar Birliği, 1977.

Yerasimos, S. Azgelişmişlik Sürecinde Türkiye [Underdevelopment Process in Turkey], vol.3. İstanbul: Gözlem Yayınları, 1976. 
